\title{
Tax Planning: As an Income Tax Saving Strategy with Cost Optimization
}

\author{
Soffia Pudji Estiasih, Rahaju Saraswati \\ WR Supratman University, Indonesia
}

\begin{abstract}
The purpose of this study is to determine the description of tax planning on income taxes that must be paid by the company. Income is one of the most popular tax objects where taxpayers tend to carry out strategies or plans for income tax. Taxes are one of the main sources of state revenue, which has a large and significant contribution to contribute to state revenue. For tax companies it is considered an expense, so that certain efforts or strategies need to be made to reduce it. The strategy that is carried out is part of tax planning, often the strategy used in this tax planning is to take advantage of the gaps contained in the taxation law.
\end{abstract}

This research was conducted by researching based on literature or library materials. This research was conducted using a conceptual approach and a statutory approach. The conceptual and regulatory approaches are carried out by examining concepts and regulations related to tax planning, income tax savings strategies and cost optimization. Sources of data used are secondary data and data collection procedures using documentation.

The results of this study indicate that tax planning is the process of organizing the taxpayer / taxpayer group's business in such a way that the tax debt is in the most minimal position, as long as this is made possible both by the provisions of taxation legislation and commercially. Cost optimization can be carried out in tax planning by changing costs with fiscal corrections to costs that can be deducted from taxable income, so that this tax planning does not contradict the law.

Keywords: Tax planning, savings strategy, income tax, cost optimization

\section{INTRODUCTION}

$\mathrm{T}$ axes are the transfer of resources from the private sector to the public sector, this transfer of resources will affect the purchasing power of the private sector. One form of public participation in carrying out economic activities, corporate taxpayers have an obligation to pay taxes. One of the tax functions is the source of State finance, which is equal to the source of State revenue which is used to finance all routine expenditures and development of the State.

Taxes are one of the main sources of state revenue, which has a large and significant contribution to contribute to state revenue. This can be seen from the outlook for the State Budget for 2019 amounting to Rp. 2,030.8 trillion, consisting of Rp. 2,029.4 trillion domestic income and Rp. 1.3 trillion. Domestic revenue was dominated by tax revenue which reached Rp. 1,643.1 trillion and the rest came from non-tax revenue reaching Rp. 386.3 trillion. With this data, tax revenue throughout 2019 only reached $80.91 \%$ of total state revenue (www.kemenkeu.go.id).

Taxes are contributions to the State (which can be enforced) owed by those who are obliged to pay them according to regulations, without getting any return, which can be directly appointed, and which are used to finance general expenses related to the state's task of administering the government (Waluyo, 2008). Definition of Income Tax Article 25, in the Income Tax Law No. 36 of 2008, states that Income Tax article 25 is the amount of tax installments that must be paid by the taxpayer for the month before the deadline for submitting an Annual Income Tax Return is the same as the amount of tax installments for the last month of the previous tax year.

In terms of the timing of the implementation of tax compliance obligations, there are differences in the interests of the taxpayers and the government. Taxpayers will try to pay the minimum tax because for companies the tax imposed on income is considered an expense in running the business and also a distribution of profits to the government. Therefore, the fulfilment of tax obligations must be managed properly so as not to be owed back in the future. Management of tax obligations is often associated with the term tax management. Tax planning is part of tax management. Tax planning is the process of organizing the business of taxpayers or groups of taxpayers in such a way that their tax debt, both income tax and other taxes, is in the most minimal position, as long as this is possible both by the provisions of tax laws and regulations. Commercially". (Zain, 2006).

According to Pohan (2018), Tax Planning is a series of strategies to regulate corporate accounting and finances to minimize tax obligations in ways that do not violate regulations (In Legal Way). So tax planning is a strategy in taxation that aims to minimize the tax burden owed by taxpayers. This strategy is by optimizing the costs incurred by the company in accordance with Article 6 of Law Number 7 of 1983 as amended several times, most recently by Law Number 36 of 2008 concerning Income Tax (hereinafter only referred to as the Tax Law. Income). Tax planning is the main concern of companies, understanding the tax consequences of planning is the most important thing in corporate taxation (Wang, 2010). According to Appolos et.al (2016), tax planning will have a positive impact on a company's cash flow and increase the rate of return, and conversely there are potential costs that are calculated in relation to tax minimizing 
strategies such as implementation and transaction costs, penalties imposed by tax authorities. According to Noor et.al (2010), American companies are known to have a high tax burden. The increase in tax rates encourages companies to practice tax planning and tax avoidance to reduce tax liability. Companies can take advantage of all opportunities for tax savings. Most of the companies make use of tax avoidance extensively since the income tax burden will reduce the company's profit. Meanwhile, Desai and Dharmapala (2009) state that tax avoidance also requires complexity to prevent early detection.

In terms of cost optimization, it can be done by converting company costs which are positively corrected fiscal into expenses that can be deducted from gross income. The fiscal correction occurs because of differences in cost recognition between fiscal accounting and commercial accounting. The differences between commercial financial reports and fiscal financial reports can be grouped into two, namely: timing differences and permanent differences. So, commercial financial reports that are reconciled with fiscal corrections will produce fiscal financial reports. Optimizing costs in minimizing Income Tax, among others: 1). Take maximum advantage of various exemptions from deductions or deductions on gross income. 2). Reducing costs that have nothing to do with the company's business activities. 3). providing benefits to employees in the form of money, not in kind. The income tax calculation scheme is shown in table 1

Table 1 Income Tax Calculation schemes

\begin{tabular}{|c|c|c|c|}
\hline $\begin{array}{l}1 . \\
2 .\end{array}$ & $(-)$ & $\begin{array}{l}\text { Total income } \\
\text { Income that is not subject to } \\
\operatorname{tax}\end{array}$ & $\begin{array}{c}\text { Article } 4 \text { Paragraph } \\
\text { (1) } \\
\text { Article } 4 \text { Paragraph } \\
\text { (3) }\end{array}$ \\
\hline 4. & $\begin{array}{l}(=) \\
(-)\end{array}$ & $\begin{array}{l}\text { Gross income }(1-2) \\
\text { Deductible fiscal costs } \\
\text { Correction: Fiscal costs } \\
\text { cannot be reduced }\end{array}$ & $\begin{array}{c}\text { Article } 6 \text { Paragraph } \\
\text { (1) } \\
\text { Article 11, Article 11A } \\
\text { Article } 9 \text { Paragraph (1) } \\
\text { (2) }\end{array}$ \\
\hline $\begin{array}{l}5 . \\
6 . \\
7 .\end{array}$ & $\begin{array}{l}(=) \\
(-) \\
(-)\end{array}$ & $\begin{array}{c}\text { Net Income (3-4) } \\
\text { Compensation for Losses } \\
\text { Non-Taxable Income } \\
\text { (Personal WP) }\end{array}$ & $\begin{array}{l}\text { Article } 6 \text { Paragraph (2) } \\
\text { Article } 7 \text { Paragraph (1) }\end{array}$ \\
\hline $\begin{array}{l}8 \\
9 .\end{array}$ & $\begin{array}{l}(=) \\
(\mathrm{x})\end{array}$ & $\begin{array}{c}\text { Taxable Income (5-6-7) } \\
\text { Rates }\end{array}$ & Article 17 \\
\hline $\begin{array}{l}10 . \\
11 .\end{array}$ & $\begin{array}{l}(=) \\
(-)\end{array}$ & $\begin{array}{c}\text { Income Tax Payable }(8 \times 9) \\
\text { Tax Credit }\end{array}$ & $\begin{array}{c}\text { Article } 21, \text { Article 22, } \\
\text { Article 23, Article 24, } \\
\text { Article } 25\end{array}$ \\
\hline 12. & $(=)$ & $\begin{array}{l}\text { Underpayment / Overpayment } \\
\text { / Zero Income Taxes (10-11) }\end{array}$ & $\begin{array}{c}\text { Article } 28 \\
\text { Article } 28 \mathrm{~A}, \text { Article } 29\end{array}$ \\
\hline
\end{tabular}

Source: Income Tax Law No. 36 of 2008

Profit is an important aspect for a company that is used for the long term in order to maintain business continuity. A company will always try to increase profits in a sustainable manner. The problem is that the greater the profit a company receives, the greater the tax borne by the company. The impact is that companies have to pay a large amount of their payable taxes. In fact, tax payments can be minimized through tax planning. The purpose of this study is to determine the description of the tax planning on the income tax that must be paid by the company.

\section{LITERATURE REVIEW}

\section{Income tax}

Based on Article 1 Paragraph (1) of Law Number 6 Year 1983 as amended several times, most recently by Law Number 28 Year 2007 concerning General provisions and Tax Procedures (hereinafter only referred to as the Law on General Tax Provisions) tax is compulsory contributions to the state that are owed by private persons or entities that are compelling based on law, without receiving direct compensation and used for the purposes of the state for the greatest prosperity of the people.

Administratively, tax collections are grouped into 2, namely direct taxes and indirect taxes. Direct taxes are imposed on the inflow of resource sources, namely income earned by taxpayers, while indirect taxes are imposed on the exit of resources such as expenditures on consumption of goods and services by the community. The tax burden is directly borne by the taxpayer (individual / entity) who receives / earns income, while the indirect tax burden is borne by the public. So tax is a burden for society, therefore society needs a good tax planning so that the tax burden borne by the community can be minimized.

Income is one of the most popular tax objects where taxpayers tend to carry out strategies or plans for income tax. Indonesian Accountants Association in PSAK No. 46 (2017), defines income tax as a tax calculated based on tax regulations and this tax is charged on taxable income. Meanwhile, according to article 1 of the income tax law, No. 36 of 2008 income tax is imposed on the tax subject on income received or earned in the tax year.

\section{Income tax subject}

The subjects of income tax according to Article 2 of the Income Tax Law Number 36 of 2008 are:

a. Individuals who do not reside in Indonesia, individuals who are in Indonesia for not more than 183 days within a period of 12 months and entities that are not established and are not domiciled in Indonesia, which carry out business or carry out activities through a business establishment in Indonesia.

b. Individuals who do not reside in Indonesia, individuals who are in Indonesia for not more than 183 days within a period of 12 months, and bodies which are not established and are not domiciled in Indonesia, which can receive or obtain income from Indonesia not from running a business or carrying out activities through a permanent establishment in Indonesia. 


\section{Income Tax Objects}

The object of income tax is income, which according to Article 4 Paragraph (1) of the Income Tax Law Number 36 of 2008 is any additional economic capacity received or obtained by a Taxpayer, whether originating from Indonesia or from outside Indonesia, which can be used for consumption. or to increase the wealth of the taxpayer concerned, under whatever name and form.

\section{Tax Management Objectives}

In achieving these tax management objectives, it can be achieved through management functions such as:

\section{1) Tax Planning}

Tax planning is the first step in tax management. At this stage, taxation regulations are collected and researched in order to select the types of tax savings measures that can be taken.

\section{2) Implementation of tax obligations}

After knowing the factors that will be used to make tax savings, the next step is to implement it in accordance with the applicable Tax Regulations. Two important things in implementing tax obligations are:

\section{a. Understand the provisions of tax regulations}

With the existence of tax regulations such as Laws, Government regulations, Minister of Finance Regulations, Directorate General of Taxes Regulations, and other related regulations, it is possible to identify opportunities that can be used to save the tax burden owed.

\section{b. Organizing the opening that meets the requirements}

Bookkeeping is an important means of presenting company financial information which is presented in the form of financial statements and serves as the basis for calculating the amount of tax payable.

\section{3) Tax Control}

Tax Control aims to ensure that tax obligations have been carried out as planned. In this matter what is important is the inspection of tax payments. Therefore, controlling and controlling cash flow is very important in tax savings strategies, for example making tax payments at the last minute is certainly more profitable when compared to paying early.

\section{Tax Planning}

Planning is the process of determining organizational goals which then clearly presents the strategies and tactics needed to achieve the company as a whole (Suandy, 2011). Based on the Law on General Provisions of Taxation, tax is a mandatory contribution to the State that is owed by an individual or a compelling entity based on the Law, without receiving direct compensation and being used for the state's needs for the greatest prosperity of the people.

Tax planning is the process of organizing the business of a Taxpayer / Taxpayer group in such a way that the tax debt, both Income Tax and other taxes, is in the most minimal position, as long as this is made possible by the provisions of tax laws and regulations. And commercially"(Zain, 2006). Tax planning is the first step in tax management. The purpose of tax planning is to manipulate so that the tax burden can be reduced as low as possible by utilizing existing regulations. Tax planning for Income Tax is inseparable from the tax collection system adopted in Indonesia, namely the selfassessment system where taxpayers are given the confidence to calculate, pay and report their tax obligations themselves, so that through this system the implementation of tax administration is expected to be carried out more neatly, in a controlled manner, and easy to understand by the taxpayers themselves.

Efforts to save tax legally can be done through tax management. Tax management itself is a means to fulfill tax obligations properly but the amount of tax paid can be kept as low as possible to obtain maximum profit. The motivation underlying tax planning generally comes from 3 elements, namely:

1. Taxation policy: alternatives of various targets to be aimed at in the taxation system which concerns such as what taxes will be collected, tax subjects, tax objects, rates, and procedures.

2. Taxation law: there is a section for taxpayers to analyze existing opportunities carefully in planning a good tax because of the implementation provisions (Government Regulations, Presidential Decrees, Decree of the Minister of Finance, and Decree of the Directorate General of Taxes) with the tax law itself.

3. Tax administration: where companies carry out tax regulations properly in order to avoid administrative / criminal sanctions due to differences in interpretation between tax authorities and taxpayers as a result of the extent of taxation regulations in force and information systems that are still ineffective (Suandy, 2011)

According to Pohan (2018) strategies that can be taken to make legal tax burdens more efficient, namely:

1. Tax Saving, is an effort to streamline the tax burden by selecting alternative tax charges with lower rates.

2. Tax Avoidance, is an effort to streamline the tax burden by avoiding taxation by directing it to transactions that are not tax objects.

3. Tax Payment Delay. Delaying payment of tax obligations without violating applicable regulations can be done through postponing Value Added Tax payments. This delay is done by postponing the issuance of the output tax invoice until the time limit allowed. 
4. Optimizing the Allowable Tax Credit. Taxpayers often lack information regarding creditable tax payments which are prepaid taxes. For example, Income Tax Article 22 or the purchase of diesel fuel and imports and foreign fiscal policy for official trips.

5. Avoid Tax Audits by avoiding Overpayments

6. Avoid Violation of Tax Regulations.

\section{Tax Planning Benefits}

The benefits of tax planning in general are savings in cash out, in this case tax planning can reduce the tax burden to be issued and regulate cash flow (tax planning can estimate cash requirements for taxes and determine payments so that companies can prepare more accurate cash budgets).

Some things that must be considered in tax planning:

1. Does not violate tax provisions

2. Makes business sense. Because tax planning is an inseparable part of the company's overall planning, both short and long term.

3. Sufficient supporting evidence, for example evidence of agreements, invoices, and also the accounting treatment (Suandy, 2011).

\section{Cost Optimization}

Costs are the decrease in economic benefits during an accounting period in the form of cash outflows or reduced assets. (Suandy, 2011). Cost optimization can be done by converting costs that are fiscal corrections into costs that can be deducted from taxable income (Article 6 of the Income Tax Law Number 36 of 2008). Costs that can be optimized through a tax planning approach are:

1. Providing benefits to employees in the form of money / in kind, because basically gifts in kind can be deducted as expenses by the employer as long as the provision is calculated as income which is subject to tax for the employee who receives it, for example :

a) Article 21 Employee Income Tax

Income tax allowance provided to employees is an allowance in the form of money provided by the employer to assist employees in paying income tax. If Income Tax benefits are provided to employees, then for employees the income tax benefits are income so that they can be taxed, while for employers / companies the income tax benefits can be deducted from the company's Taxable employers and included as income tax benefits.

b) Medical or employee health

If employees are given medical allowances in the form of cash, this will constitute income for the employees and are subject to Income Tax. Thus this cash payment can be deducted as company costs and increases the income tax burden of the employee concerned.

\section{Entertainment fees}

Changing entertainment fees that do not have a nominative list to become entertainment fees accompanied by a nominative list so that they can be charged as fees in calculating taxable income (Director General of Taxes Circular Letter Number SE-27 / PJ.22 / 1986).

Cost optimization can also include sales product prices, administrative and sales costs, and other costs in carrying out company operational activities (Regulation of the Minister of Finance of the Republic of Indonesia Number 02 / PMK.03 / 2010). This administration and sales cost optimization is carried out against costs that are not allowed under taxation provisions in accordance with Article 9 of the Income Tax Law, so that in the end these costs can be deducted in the calculation of taxable income and net profit before corporate tax can be minimized. Optimization of these costs can be done in several ways, namely: 1 , Switching the provision of company fees that are in kind or enjoyment to employees who were not previously taxed, the tax can be planned by providing various kinds of allowances to employees so that employees can be taxed and for the company it can be used. as a deduction from income, for example: Tax Income which is borne by the company. 2, Provide supporting evidence for expenses that require supporting evidence so that they can be deducted in the calculation of taxable income such as official travel expenses.

\section{Stages in Making Tax Planning}

Suandy (2011) states that in order for tax planning to be successful as expected, the plan should be carried out through the following sequence of stages:

\section{Analyzing the existing information (Database)}

The first stage of tax planning is to analyze the different components of the tax involved in a project and calculate as accurately as possible the tax burden incurred. This can only be done by considering each element of the tax, either individually or in total tax which must be formulated as the most efficient tax planning.

\section{Create one or more tax rate plans.}

The model is needed to provide a clear picture of the calculation of tax planning, the model should be made more than one, so that they can be compared.

\section{Evaluation of Tax Planning}

Tax planning as a plan that is a small part of the company's entire strategic planning, therefore it is necessary to evaluate to see the extent to which the results of the implementation of a tax plan on the tax burden, differences in gross profit, and non-tax expenditures on various planning alternatives.

\section{Look for Weaknesses and Then Revise Tax Plans}

The results of a good tax planning or not, of course, must be evaluated through various plans made. Up to date planning must be carried out even if additional costs are required or the 
probability of success is very small. As long as the tax savings are still large, the plan must be carried out, because after all the losses incurred are minimal losses.

\section{Updating the Tax Plan}

Even though a tax plan has been implemented and the project has also been running, it is still necessary to take into account any changes that occur, both from the Law and its implementation.

\section{RESEARCH METHODS}

This type of research is literature research, this research is carried out by researching based on literature or library materials. This study uses a conceptual approach and a statutory approach. The conceptual and regulatory approaches are carried out by examining concepts and regulations related to tax planning, income tax savings strategies and cost optimization. Sources of data used are secondary data and data collection procedures using documentation.

\section{DISCUSSION}

Each company in carrying out accounting activities has different policies, these policies greatly affect the quality of the presentation of financial statements in order to obtain maximum profit. As a profit-oriented company, the profits earned will be taxed in accordance with tax laws and regulations. As a taxpayer, every company must comply with and carry out its tax obligations in accordance with tax laws. It is no longer a secret, if there are efforts made by taxpayers, to regulate the amount of tax to be paid. For companies, taxes are considered a cost, so it is necessary to make certain efforts or strategies to reduce them. Companies are trying to minimize the tax burden, this can be done by means of tax savings through tax planning. With tax savings, the company's cash outflow will be smaller so that companies can use the money for investment development.

Tax planning in a company is important to minimize and streamline the tax burden owed by the company. Tax planning is not at all aimed at manipulating taxation, but seeks to take advantage of opportunities related to taxation regulations that benefit taxpayers and do not harm the government and in a legal way. Therefore, tax management is needed through tax planning which aims to reduce taxes and to save taxes. Tax management itself is a means to fulfill tax obligations properly, but the amount of tax paid can be kept to a minimum to obtain the expected profit.

Tax Planning is the initial stage for carrying out a systematic analysis of various tax treatments with the aim of achieving the fulfillment of minimum tax obligations. A company manager must be able to put in effort in carrying out tax planning appropriately by paying attention to transactions that have an impact on tax planning calculations. Darussalam and Septriadi (2009) state that tax planning is an attempt by taxpayers to minimize their payable tax through a scheme that is clearly regulated in taxation regulations and does not cause disputes between taxpayers and tax authorities. The exploitation of this loophole in taxation regulations causes tax planning to be considered legal and not against the law, and does not lead to tax evasion. To continue to fulfill tax obligations properly, corporate taxpayers need tax planning so that the tax amount can be reduced as low as possible to achieve maximum profit. According to Zain (2006), tax planning is a structural action related to the potential tax consequences, which emphasizes controlling every transaction that has tax consequences. The goal is how this control can streamline the amount of tax to be transferred to the government, through what is known as tax avoidance and not tax evasion, which is a fiscal crime that will not be tolerated.

Income tax savings strategy with cost optimization is tax planning carried out by companies to streamline the payment of taxes owed to:

A. Costs that are not allowed as a deduction from the company's gross income according to tax regulations.

Deductions or fees that are allowed to be deducted from gross income to calculate the amount of taxable income for corporate taxpayers and permanent establishments in accordance with article 6 paragraph (1) of the Income Tax Law.

Article 6 (1) The amount of Taxable Income for resident Taxpayers and permanent establishments is determined based on gross income minus costs to obtain, collect and maintain income, including :

1. Costs that are directly or indirectly related to business activities include: costs for purchasing materials; costs related to work or services including wages, salaries, honoraria, bonuses, gratuities and allowances provided in the form of money; interest, rent and royalties; travel expense; waste treatment costs; insurance premium; promotion and sales costs that are regulated by or based on a Regulation of the Minister of Finance; administrative costs; and taxes except income tax

2. Depreciation of expenditures to acquire tangible assets and amortization of expenses for obtaining rights and other costs which have a useful life of more than 1 year as referred to in Article 11 and Article 11A;

3. Contribution to pension funds whose establishment has been approved by the Minister of Finance;

4. Losses due to the sale or transfer of property owned and used in the company or owned to obtain, collect and maintain income;

5. Loss on foreign exchange rates;

6. Research and development costs for companies carried out in Indonesia;

7. Scholarship, internship and training costs; 
8. Receivables that are apparently uncollectible on condition that: Has been charged as expense in the statement of commercial income; Taxpayers must submit a list of uncollectible receivables to the Directorate General of Taxes; The collection case has been submitted to the District Court or the government agency that handles state receivables; or there is a written agreement regarding the write-off of accounts receivable / debt relief between the creditor and the debtor concerned; or has been published in a public or special publication; or there is an acknowledgment from the debtor that the debt has been written off for a certain amount of debt; The requirements as referred to in point 3 do not apply to the write-off of bad debts from small debtors as referred to in Article 4 paragraph (1) letter k; whose implementation is further regulated by or based on a Regulation of the Minister of Finance;

9. Contributions in the context of national disaster management, the provisions of which are regulated by a Government Regulation;

10. Contributions for research and development carried out in Indonesia which are stipulated by a Government Regulation;

11. Social infrastructure development costs, the provisions of which are regulated by a Government Regulation;

12. Contribution of educational facilities, the provisions of which are regulated by a Government Regulation;

13. Contribution in the framework of sports fostering the provisions of which are regulated by a Government Regulation.

Article 6 (2) If the gross income after deduction as referred to in paragraph (1) is obtained a loss, the loss shall be compensated with income starting from the next tax year for up to 5 (five) consecutive years. Article 6 (3) Individuals as resident Taxpayers are given a deduction in the form of Non-Taxable Income as referred to in Article 7.

B. Expenses that can be deducted from the company's gross income according to tax regulations.

Costs that cannot be deducted from gross income Deductions or fees that are not allowed to be deducted from gross income to calculate the amount of taxable income for corporate and permanent business taxpayers in accordance with article 9 paragraph (1) of the Income Tax Law.

Article 9 (1) To determine the amount of Taxable Income for a resident Taxpayer and a permanent establishment, it may not be deducted:

a. Profit distribution in whatever name and form, such as dividends, including dividends paid by insurance companies to policyholders, and distribution of the remainder of the cooperative's operating income;

b. Costs that are charged or incurred for the personal benefit of shareholders, partners or members;

c. Establishment or accumulation of reserve funds, except: 1. reserves for uncollectible accounts for banks and other business entities that extend credit, leasing with option rights, consumer finance companies, and factoring companies; 2. reserves for insurance businesses including social assistance reserves established by the Social Security Administering Body; 3 . The guarantee reserve for the Deposit Insurance Corporation; 4. reserves for reclamation costs for mining businesses; 5 . reserves for replanting costs for forestry businesses; and 6 . reserves for costs for the closure and maintenance of industrial waste disposal sites for industrial waste processing businesses, the terms and conditions of which are regulated by or based on a Regulation of the Minister of Finance;

d. Health insurance premiums, accident insurance, life insurance, endowment insurance, and student scholarship insurance, which is paid by an individual taxpayer, unless paid by the employer and the premium is calculated as income for the taxpayer concerned; Establishment or accumulation of reserve funds, except: 1. reserves for uncollectible accounts for banks and other business entities that extend credit, leasing with option rights, consumer finance companies, and factoring companies; 2 . reserves for insurance businesses including social assistance reserves established by the Social Security Administering Body; 3. The guarantee reserve for the Deposit Insurance Corporation; 4. reserves for reclamation costs for mining businesses; 5 . reserves for replanting costs for forestry businesses; and 6 . reserves for costs for the closure and maintenance of industrial waste disposal sites for industrial waste processing businesses, the terms and conditions of which are regulated by or based on a Regulation of the Minister of Finance;

e. Replacement or remuneration in connection with work or services provided in the form of in kind and enjoyment, except for the provision of food and drink for all employees as well as replacement or compensation in the form of in kind and enjoyment in certain areas and in connection with the implementation of work regulated by or based on a Regulation of the Minister of Finance ;

f. An amount that exceeds the fairness paid to shareholders or to related parties as compensation in connection with the work performed;

g. The donated assets, assistance or donations, and inheritance as referred to in Article 4 paragraph (3) 
letter a and letter $b$, except donations as referred to in Article 6 paragraph (1) letter i to letter $\mathrm{m}$ and zakat received by the amil zakat body or amil zakat institutions established or legalized by the government or mandatory religious donations for adherents of recognized religions in Indonesia, received by religious institutions established or legalized by the government, the provisions of which are regulated by or based on Government Regulations;

h. Income tax;

i. Costs that are charged or incurred for the personal benefit of the Taxpayer or his dependent; $j$. salaries paid to members of an association, firm, or limited partnership whose capital does not consist of shares; $\mathrm{k}$. administrative sanctions in the form of interest, fines and increases as well as criminal sanctions in the form of fines relating to the implementation of laws in the field of taxation.

Article 9 (2) Expenditures to obtain, collect and maintain income which has a useful life of more than 1 (one) year are not allowed to be charged at once, but rather through depreciation or amortization as referred to in Article 11 or Article 11A.

Steps in Tax planning:

1. Maximizing the income that is excluded in the Income Tax Law Article 4 paragraph (3) regulates income that is exempted as a tax object. In addition to income that is exempted by law, we also have to know what is included in the income in the law so that we can know for sure what tax planning will be carried out.

2. Maximizing fiscal costs by minimizing taxes payable is carried out with tax planning (Suandy, 2011).

Lumbantoruan (2005), steps that can be taken in order to maximize income exempted in Article 4 (3) of the Income Tax Law are as follows:

a. Changing the type of income by taking advantage of the loopholes of the applicable taxation law, efforts to make an effort to make taxable income exempt or reduce the amount of tax are made.

b. Planning income for the following year To minimize tax for the year concerned, the income earned in the last months of the year is planned as next year's income.

c. Taking the maximum or maximum possible profit from the various exemptions from deductions from taxable income that are allowed by law, if it is known that taxable income (profits) of large companies will be subject to high / highest tax rates, then the company should spend part of the company's profits. for matters that are directly beneficial to the company on condition that the costs incurred are costs that can be deducted from the taxable income (deductible)..

Matters that need to be considered in order to carry out tax planning are:

a. Taxpayers must determine the goals to be achieved in tax planning. Tax planning has at least two main objectives, namely: implementing tax regulations correctly and streamlining the expected profit (Suandy, 2011).

b. Taxpayers must understand the related tax regulations. The implementation of tax planning must be designed in the corridor of the applicable Taxation Law and not violate the rules if tax planning is implemented, the success of tax planning can be achieved if the taxpayer can avoid things that can harm the taxpayer themselves.

c. Taxpayers must have accounting policies that are supported by adequate evidence, such as official documents, Standard Operational Procedures, agreements, and others.

d. In carrying out tax planning, taxpayers must understand the fairness level of transactions and the character of their business. This is because each company must have differences in determining any policies, understanding these policies will be very helpful in carrying out tax planning.

\section{CONCLUSION}

What must be considered in tax planning is to minimize costs which according to the taxation law cannot be deducted, this will cause the income before tax to be greater and may result in higher tax payable Fiscal costs are expenses that according to the Taxation Law can be deducted from gross income. The greater the fiscal costs that can be deducted from gross income, the smaller the net profit before tax and will automatically reduce the tax payable. Therefore, in carrying out tax planning, we must know the costs that are allowed as deductions and costs that are not allowed as deductions. The main thing in regulating the amount of tax to be paid to a minimum is a basic knowledge of the tax regulations themselves. Because, this is done by exploiting loopholes or things that have not been regulated in the Law.

\section{SUGGESTION}

1. Companies must be careful in charging costs related to tax planning, because not all costs can be recognized in a fiscal manner

2. Companies must carry out tax obligations (tax implementation) and tax control (tax control).

\section{BIBLIOGRAPHY}

[1] Appolos N, * Kwarbai Jerry D., and Ogundajo, Grace O. 2016. Tax Planning and Firm Value: Empirical Evidence from Nigerian Consumer Goods Industrial Sector. Research Journal of Finance and Accounting. ISSN 2222-1697 (Paper) ISSN 2222-2847 (Online). Vol.7, No.12, 2016 
[2] Darussalam, D.Septriadi. 2009. Tax Avoidance, Tax Planning, Tax Evasion, dan Anti Avoidance Rule. (http://www.ortax.org/ortax/?mod=issue\&page=show\&id=36\&q= \&hlm=2. Diakses 6 Januari 2021)

[3] Desai, M. A. and Dharmapala D. 2009. "Corporate tax avoidance and firm value". The Review of Economics and Statistics, 91 (3), pp. 537-546.

[4] Ikatan Akuntansi Indonesia. 2017. Pernyataan Standar Akuntansi Keuangan (PSAK) No. 46: Akuntansi Pajak. Jakarta. IAI.

[5] Lumbantoruan, Sophar. 2005. Akuntansi Pajak. PT. Grasindo. Jakarta

[6] Noor, Rohaya Md, Nur Syazwani M. Fadzillah and Nor'Azam Mastuki. 2010. Corporate Tax Planning: A Study on Corporate Effective Tax Rates of Malasyia Listed Companie. International Journal of Trade, Economics and Finance, Vol. 1, No. 2, August, 2010 2010-023X

[7] Pohan, Chairil Anwar. 2018. Manajemen Perpajakan Strategi Perencanaan Pajak dan Bisnis. Jakarta. PT Gramedia Pustaka Utama.
[8] Republik Indonesia. 2007. Undang-undang Nomor 6 Tahun 1983 sebagaimana telah beberapa kali diubah terkahir dengan Undang-Undang Nomor 28 Tahun 2007 tentang Ketentuan Umum dan Tata Cara Perpajakan

[9] Republik Indonesia. 2008. Undang-Undang nomor 36 tahun 2008 Tentang Perubahan keempat Atas Undang-Undang Nomor 7 Tahun 1983 Tentang Pajak Penghasilan.

[10] Peraturan Menteri Keuangan RI Nomor 02/PMK.03/2010 Tentang Biaya Promosi yang Dapat Dikurangkan Dari Penghasilan Bruto

[11] Suandy, Erly. 2011. Perencanaan Pajak. Edisi 5. Jakarta. Salemba Empat.

[12] Surat Edaran Dirjen Pajak Nomor SE-27/PJ.22/1986 Tentang Biaya Entertainment dan Sejenisnya

[13] Wang, H., Davidson, W. And Wang, X. 2010. "The SarbanesOxley Act and Ceo Tenure, turnover and risk aversion". The quarterly Review of Economics and Finance. 50. pp.367-376.

[14] Waluyo. 2008. Akuntansi Pajak. Jilid I. Jakarta. Salemba Empat.www.kemenkeu.go.id

[15] Zain, Mohammad. 2006. Manajemen Perpajakan. Edisi Pertama. Jakarta. Salemba Empat. 